\title{
Discovering the Relative Efficacy of Inhaled Medications for Chronic Obstructive Pulmonary Disease: Multiple Treatment Comparisons
}

\author{
Ying Zhu ${ }^{a}$ Tong Zhang ${ }^{a}$ Haiyan Lib YangYang ${ }^{c}$ Qiong Chen ${ }^{d}$ Lei Konge Bo Tai ${ }^{f}$

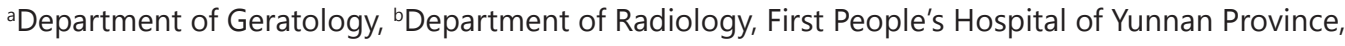 \\ 'Faculty of Life Science and Technology, Kunming University of Science and Technology, Kunming, \\ Yunnan, 'Lincang Health School of Yunnan Province, Lincang, Yunnan, eSchool Infirmary of Kunming \\ Medical University, fDepartment of Neurosurgery, First People's Hospital of Yunnan Province, Kunming, \\ Yunnan, China
}

\section{Key Words}

Chronic obstructive pulmonary disease $\cdot$ Inhaled corticosteroids $\bullet$ Long-acting Beta 2-agonist - Long-acting muscarinic antagonist • tFEV1 • St George's Respiratory Questionnaire

\begin{abstract}
Background: Chronic obstructive pulmonary disease (COPD) is managed by three major classes of inhaled medications: inhaled corticosteroids (ICS), long-acting Beta 2-agonist (LABA), long-acting muscarinic antagonist (LAMA). Single inhaled medication is usually replaced by combined inhaled medications for efficacy enhancement. However, this practice should be supported by clinical evidence for large-scale implementations. Methods: The relative efficacy of inhaled medications is determined by three endpoints: changes in the trough forced expiratory volume in 1 second ( $\mathrm{tFEV}_{1}$ ), changes in the St George's Respiratory Questionnaire (SGRQ) score and the proportion of SGRQ responders which represents a reduction in SGRQ total score at week 24 of $\geqslant 4.0$. A total of 76 eligible studies were identified in PubMed and Embase. Relevant data were extracted for the purpose of evidence synthesis. Then, raw mean differences (MD) and odds ratios (ORs) were produced by using the network meta-analysis. Results: Patients with ICS + LABA, ICS + LABA + LAMA, LABA, LABA + LAMA, LAMA exhibited significant increases in the tFEV1 compared to those with placebo $(P<0.05)$. Moreover, patients with ICS + LABA + LAMA exhibited the largest increase in the average tFEV1 and the largest decrease in the average SGRQ scores compared to those with placebo. COPD patients with ICS + LABA + LAMA were far more likely to achieve a significant reduction in the SGRQ scores compared to those with placebo or other inhaled medications (OR $>1$ ). Conclusions: The combined inhaled medication of ICS + LABA + LAMA may be more efficacious than other inhaled medications for COPD patients.




\section{Introduction}

Chronic obstructive pulmonary disease (COPD) is an irreversible disease which is characterized by a progressive decline in pulmonary functions. COPD is often accompanied by some respiratory symptoms including dyspnea, cough and sputum production [1]. The high prevalence of COPD has become a global issue due to the large aging population [2]. A wide variety of inhaled medications have been developed and they appear to have different levels of efficacy with respect to lung function restoration and COPD symptom control $[3,4]$.

Current guidelines made by the Global Initiative for COPD (GOLD) recommend the use of inhaled medications such as long-acting $\beta$ agonist (LABA) or long-acting muscarinic antagonist (LAMA) for symptomatic patients who suffered from moderate or severe COPD [5]. Both LAMA (Tiotropium, Glycopyrronium, Aclidinium Bromide) [6] and LABA (Salmeterol, Formoterol, Indacaterol) have been approved as inhaled medications for COPD patients $[7,8]$. Alternatively, LAMA and LABA can be combined with each other in order to enhance the efficacy.

The current medication strategy for COPD patients is based on disease classification, but combined inhaled medications may be introduced if single inhaled medication is not effective [9]. For instance, LABA + LAMA may be more efficacious than single inhaled medication, but such combined medications have not been thoroughly investigated $[10$, 11]. The newly-adopted disease classification approach takes account both symptoms and exacerbation risks. As a result, combined inhaled medications may be introduced if patients exhibited specific symptoms. For instance, inhaled corticosteroids (ICS) can be combined with LABA or LAMA in the case that COPD is accompanied with asthma [12]. Also, ICS + LABA is able to suppress the exacerbation of COPD for those who had low forced expiratory volume [13]. Currently, incorporating ICS, LABA and LAMA has become popular in clinical practices. However, no conclusive evidence has been disclosed from the current literature and few systematic reviews have been performed to assess its relative efficacy [14, 15].

Three popular efficacy endpoints were selected in order to determine the relative efficacy of inhaled medications: trough forced expiratory volume in 1 second $\left(\mathrm{tFEV}_{1}\right)$, St George's Respiratory Questionnaire (SGRQ) score and the proportion of SGRQ responders [16]. The implementation of network meta-analysis (NMA) may produce extra evidence which cannot be achieved by using conventional meta-analysis.

\section{Material and Methods}

\section{Literature retrieval strategy}

We began our research by conducting a systematic review of approved inhaled medications that are classified as ICS, LABA or LAMA. The following inhaled medications are included in our literature search and review process: aclidinium, arformoterol, beclomethasone, formoterol, budesonide, tiotropium, fluticasone furoate, vilanterol, fluticasone propionate, salmeterol, fluticasone, glycopyrronium, indacaterol, ipratropium, mometasone furoate, olodaterol, umeclidinium and vilanterol. Then, a rigorous literature searching strategy was designed and input into online databases including PubMed and Embase in order to retrieve relevant studies. The above searching process was conducted by two reviewers independently and only studies published in English were included. Additional literature search was conducted by reviewing the reference list of retrieved articles and key cited references were included in our study if they appeared to be relevant to our research objectives. The title, abstract and content of retrieved articles were sequentially reviewed by two independent reviewers. Any discrepancy with respect to literature search, identification and screening was solved by discussion.

Determine the eligibility of studies

We designed the following eligible criteria for studies to be included in our NMA: 1) double-blind randomized clinical trials (RCTs) that compared at least one of the above inhaled medications; 2) sufficient information with respect to $\mathrm{FEV}_{1}$, SGRQ scores or SGRQ responders; 3) studies carried out between 2005 


\section{Cellular Physiology Cell Physiol Biochem 2017;41:1532-1546 \begin{tabular}{l|l} 
DOI: 10.1159/000470818 & O 2017 The Author(s). Published by S. Karger AG, Basel \\
www.karger.com/cpb
\end{tabular} \\ Zhu et al.: Efficacy of Inhaled Medications for COPD}

and 2015 with study duration ranging from four weeks to two years; 4) studies published in English. Duplicated studies, case reports, reviews and studies without sufficient data were excluded from the eligible list.

\section{Selection of clinical outcomes}

The trough forced expiratory volume in 1 second $\left(\mathrm{tFEV}_{1}\right)$ is a popular measurement that can be used to assess lung function and monitor the progress of COPD over time and therefore it was selected as the primary efficacy outcome [17]. A significant increase in the $\mathrm{HFEV}_{1}$ during the study period indicates significant improvements in lung functions. Since the included studies disclose the study duration instead of the medication duration, we assume the two to be approximately equal to each other. The second key outcome of our interest is the SGRQ score which is a standardized self-evaluated questionnaire for measuring both health status and well-being of patients with airway disease [18]. A total of 50 questions were incorporated in the SGRQ, which simultaneously quantifies disease severity, disease syndrome and life quality of patients. The score of SGRQ ranges between 0 and 100. A score of zero indicates that COPD does not have any effect on the daily activity of patients whereas a score of 100 indicates that COPD significantly impairs the well-being of COPD patients. More importantly, a change in SGRQ score $\geq 4$ units is defined as clinical significant. We also selected the binary outcome of SGRQ responders: whether a COPD patient exhibited a reduction in SGRQ score $\geq 4$ units during the study period. The above three endpoints were selected in three broad aspects: COPD symptoms control, lung function restoration and improvements in life quality.

\section{Data extraction}

Once the eligible study list was determined, data extraction was conducted by two independent reviewers and the corresponding results were examined by a third reviewer to ensure accuracy. A data extraction spreadsheet was used to record the following information of each eligible study: first author, publication year, included treatments, treatment classification, dose, study duration, sample size, average age of subjects, average pre-dose $\mathrm{tFEV}_{1}$ in both liters and percentages, $\mathrm{FEV}_{1}$ time, average $\mathrm{FEV}_{1}$ at baseline and at endpoint in liters and their corresponding sample standard deviations (SD), average changes in the $\mathrm{tFEV}_{1}$ over the study period ( $\mathrm{tFEV}_{1}$ at endpoint - $\mathrm{tFEV}_{1}$ at baseline) and sample SD, SGRQ time, average SGRQ at baseline, average SGRQ at endpoint, average changes in SGRQ (average SGRQ at endpoint - average SGRQ at baseline) and the proportion of SGRQ responders in each study group. Missing data were estimated or imputed by using the approach described by Wan et al. [19].

\section{Statistical analysis}

We adopted the Bayesian Framework for implementing NMA and three outcomes were considered for evidence synthesis: changes in $\mathrm{TFEV}_{1}$ from baseline, changes in SGRQ scores from baseline and the proportion of SGRQ responders. The implementation of NMA was performed by using the R statistical software (Version 3.2.4, The R project for statistical computing) in conjunction with the GEMTC package, and a random-effects model for each outcome is assumed to be appropriate. Moreover, a consistency model is simulated from the GEMTC package by using the Markov Chan Monte Carlo (MCMC) approach. Raw mean difference (MD) was used to synthesize evidence for continuous outcomes such as $\mathrm{tFEV}_{1}$ and SGRQ scores, whereas odds ratios (ORs) were used to compare the likelihood of SGRQ responders who are treated by two treatments. The $95 \%$ credible interval (CrI) for each summary statistics was used to assess the statistical significance of each summary effect. Ranking of interventions was performed by comparing their corresponding surface under cumulative ranking area (SUCRA). Consistency between direct and indirect evidence with respect to a particular comparison was assessed by using the node splitting approach [20]. Finally, small study effects and publication bias which may affect the validity of NMA were examined using the funnel plot. The significant level of 0.05 was set for all statistical tests.

\section{Results}

Study retrieval and selection

A total of 6,324 articles were identified by using the prescribed searching strategies. The number of articles retrieved from PubMed and Embase are 3,366 and 2,958, respectively. After the identification of articles, the corresponding results were examined before literature KARGER 
screening. We also attempted to identify other records such as unpublished articles from other sources. However, no additional records were identified. Then, we started the literature screening process by removing all duplicated articles (2,367 duplicates). Once all duplicated articles were removed, we examined the title and abstract of the remaining 3,957 articles in order to determine whether they are relevant to our research topics and 3,366 articles appeared to be irrelevant. As a result, only 592 articles passed the initial screening process and were subject to full-text review. Then, the eligibility criteria were adopted in the process of full-text review. Any articles that do not fulfill the eligibility criteria or those without access to full-text content were removed and this led to an exclusion of 515 studies. Finally, 76 studies passed the entire literature retrieval and selection process [16, 21-95]. The above process was repeated for several times in order to ensure the accuracy of the eligible study list. Two independent reviewers were responsible for conducting this process and their results were cross-examined.

\section{Study characteristic}

The characteristics of 76 eligible studies are displayed in Table 1. Study information is summarized as author, publication year, trial ID, GOLD stage of patients, inhaled medication compared in each study, study duration and the corresponding clinical outcomes assessed. Evidence obtained from direct or indirect comparisons can be illustrated by network plots. A closed-loop network is formed if all nodes within a network can be connected by either solid or dashed lines. The total number of patients included in our analysis with respect to $\mathrm{tFEV}_{1}$, SGRQ and SGRQ responders are 27,995, 19,702 and 36,152, respectively. The eligible studies cover all patients with GOLD stage I-IV. The minimum and maximum study duration is four weeks and four years, respectively. As suggested by Figure 1, comparators (inhaled medications) with respect to the endpoint of $\mathrm{tFEV}_{1}$, SGRQ and SGRQ all form closed-loop networks. Therefore, both direct and indirect evidence can be synthesized by using the approach of NMA.

Comparing different inhaled medications by using $t F E V_{1}$

Since $\mathrm{FEV}_{1}$ measures the overall performance of lung function, a significant increase in $\mathrm{tFEV}_{1}$ indicates the efficacy of inhaled medications. Average changes in $\mathrm{tFEV}_{1}$ from baseline to endpoint for each eligible study were extracted and then a summary effect comparing the raw mean difference was produced by NMA. A summary effect which is significantly larger than zero suggests that one inhaled medication (single or combined) is potentially more efficacious than another and vice versa. COPD patients with five inhaled medications exhibited significant increase in the average tFEV1 compared to those with placebo (ICS + LABA: 0.11 liters, 95\% CrI $=0.08-0.15$ liters; ICS + LABA + LAMA: 0.22 liters, $95 \% \mathrm{CrI}=$ 0.16-0.29 liters; LABA: 0.07 liters, 95\% CrI $=0.04-0.10$ liters; LABA + LAMA: 0.16 liters 95\% $\mathrm{CrI}=0.13-0.19$ liters; LAMA: 0.10 liters, $95 \% \mathrm{CrI}=0.07-0.13$ liters). Our NMA suggests that COPD patients with ICS + LABA + LAMA exhibited the largest increase in the average $\mathrm{tFEV}_{1}$ (Table 2, Fig. 2). Moreover, COPD patients with ICS + LABA + LAMA exhibited significant increase in the average $\mathrm{TEVV}_{1}$ compared to those with other inhaled medications (all raw mean difference $>0$ ). On the other hand, patients with LABA exhibited a significant decrease in the average $\mathrm{tFEV}_{1}$ in reference to those with the other four mechanisms (all raw mean difference $<0$; Table 2, Fig. 2).

\section{Comparing different inhaled medications by using SGRQ scores}

SGRQ score ranging from 0 to 100 measures how COPD affects the well-being of patients. A significant reduction in SGRQ score indicates the well-being of patients has been significantly improved by inhaled medications over the study duration. Patients with three inhaled medications exhibited significant reduction in the SGRQ scores compared to those with placebo: ICS + LABA $(-3.20,95 \% \mathrm{CrI}=-5.13$ to -1.29$)$, ICS+LABA+LAMA $(-3.69,95 \%$ $C r I=-6.95$ to -0.41$)$ and LABA $(-2.03,95 \% C r I=-3.64$ to -0.45$)$. Although ICS+LABA+LAMA appears to be significantly more efficacious than the placebo with respect to SGRQ, there

\section{KARGER}




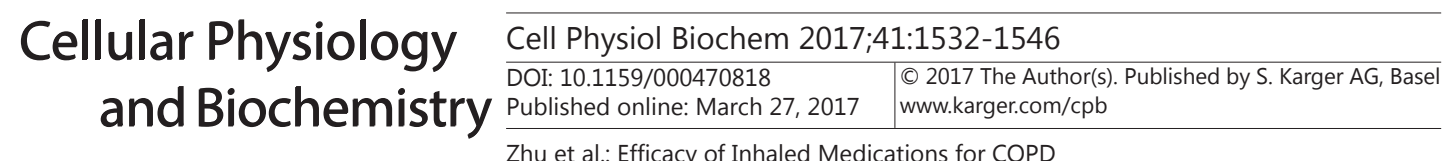

Table 1. Characteristics of the included studies. ICS inhaled corticosteroid; LABA long-acting $\beta 2$-agonist; LAMA long-acting muscarinic antagonists; tFEV1 trough forced expiratory volume in 1 second; SGRQ St George's Respiratory Questionnaire; GOLD Global Initiative for COPD

\begin{tabular}{|c|c|c|c|c|c|}
\hline Author, Year & Trial ID & GOLD stage & Inhaled medication (single or combined) & Duration & Endpoints \\
\hline Buhl, 2015 [29] & NCT01431274 & $2-4$ & LABA; LAMAL; LABA+LAMA & $52 \mathrm{wks}$ & Trough FEV1, SGRQ, SQRG Responders \\
\hline Zhong, 2015 [21] & NCT01709903 & $2-3$ & LABA+LAMA; ICS+LABA & 26 wks & Trough FEV1, SGRQ \\
\hline Zheng, 2015 [22] & NCT01636713 & $2-4$ & LABA+LAMA; Placebo & 24 wks & Trough FEV1, SGRQ, SQRG Responders \\
\hline Singh, 2015 [23] & NCT01822899 & - & LABA+LAMA; ICS+LABA & $12 \mathrm{wks}$ & Trough FEV1, SGRQ \\
\hline Siler, 2015 [24] & NCT01957163 & $2-4$ & ICS+LABA+LAMA; ICS+LABA & $12 \mathrm{wks}$ & Trough FEV1, SGRQ, SQRG Responders \\
\hline Maleki-Yazdi, 2015 [25] & NCT00452400 & $2-3$ & LABA; Placebo & $4 \mathrm{wks}$ & Trough FEV1 \\
\hline Lee, 2015 [26] & NCT01636401 & $2-3$ & LAMA; Placebo & 12 wks & Trough FEV1, SGRQ \\
\hline Ichinose, 2015 [16] & NCT00824382 & $2-4$ & LABA; Placebo & 4 wks & Trough FEV1 \\
\hline Frith, 2015 [27] & NCT01513460 & $2-3$ & ICS+LABA+LAMA; ICS+LABA+LAMA & 12 wks & Trough FEV1, SGRQ \\
\hline Donohue, 2015 [28] & NCT01817764; NCT01879410 & $2-3$ & LABA+LAMA; ICS+LABA & 12 wks & Trough FEV1 \\
\hline Buhl, 2015 [30] & NCT01120717 & $2-3$ & LABA+LAMA; LABA+LAMA & 26 wks & SGRQ, SQRG Responders \\
\hline Beeh, 2015 [31] & NCT01559116 & $2-4$ & LABA; LAMA & 6 wks & Trough FEV1 \\
\hline Aalbers, 2015 [32] & NCT01040403 & $2-3$ & LABA; LABA+LAMA & 4 wks & Trough FEV1 \\
\hline Trivedi, 2014 [34] & NCT01387230 & $2-4$ & LAMA; LAMA & $12 \mathrm{wks}$ & Trough FEV1, SGRQ \\
\hline Pepin, 2014 [36] & NCT01395888 & $2-3$ & ICS+LABA; LAMA & $12 \mathrm{wks}$ & Trough FEV1 \\
\hline Ohar, 2014 [37] & NCT01110200 & $2-3$ & ICS+LABA; LABA & 26 wks & Trough FEV1 \\
\hline Donohue, 2014 [42] & NCT00909779 & $2-3$ & LABA; Placebo & 52 wks & Trough FEV1 \\
\hline ZuWallack, 2014 [33] & NCT01694771; NCT01696058 & $2-3$ & LAMA; LABA+LAMA & 12 wks & Trough FEV1, SGRQ, SQRG Responders \\
\hline Celli, 2014 [43] & NCT01313637 & $2-4$ & LABA+LAMA; LAMA & 24 wks & Trough FEV1, SGRQ, SQRG Responders \\
\hline Singh, 2014 [35] & NCT1462942 & - & LABA+LAMA; LAMA & 24 wks & SGRQ \\
\hline Maltais, 2014 [38] & NCT01323660; NCT01328444 & $1-4$ & LABA+LAMA; LABA+LAMA & 12 wks & Trough FEV1 \\
\hline Maleki-Yazdi, 2014 [39] & NCT01777334 & $2-4$ & LABA+LAMA; LAMA & 24 wks & Trough FEV1, SGRQ, SQRG Responders \\
\hline \multirow[t]{2}{*}{ Feldman, 2014 [40] } & NCT00931385 & $2-4$ & LABA; Placebo & $6 \mathrm{wks}$ & Trough FEV1 \\
\hline & NCT00932646 & $2-4$ & LABA; Placebo & $6 \mathrm{wks}$ & Trough FEV1 \\
\hline D'Urzo, 2014 [41] & NCT01437397 & $2-3$ & LABA+LAMA; LAMA & $24 \mathrm{wks}$ & SGRQ, SQRG Responders \\
\hline Fukuchi, 2013 [44] & NCT01069289 & $2-3$ & ICS+LABA; LABA & 12 wks & SGRQ, SQRG Responders \\
\hline Donohue, 2013 [45] & NCT01313650 & $3-4$ & LABA+LAMA; LAMA & $24 \mathrm{wks}$ & SGRQ, SQRG Responders \\
\hline Decramer, 2013 [46] & NCT00845728 & & LABA; LAMA & $52 \mathrm{wks}$ & Trough FEV1, SGRQ, SQRG Responders \\
\hline Cooper, 2013 [47] & NCT00525512 & $2-3$ & LAMA; Placebo & 2 yrs & SGRQ \\
\hline Bateman, 2013 [48] & NCT01202188 & $2-3$ & LABA+LAMA; LAMA; Placebo & $26 \mathrm{wks}$ & SGRQ \\
\hline Tashkin, 2012 [49] & NCT00383435; NCT00383721 & $2-4$ & ICS+LABA; ICS; LABA; Placebo & 52 wks & SGRQ, SQRG Responders \\
\hline Sharafkhaneh, 2012 [50] & NCT00419744 & $2-4$ & ICS+LABA; LABA & $52 \mathrm{wks}$ & Trough FEV1, SGRQ \\
\hline Scherr, $2012[51]$ & NCT00860938 & $1-2$ & ICS+LAMA; LAMA & $16 \mathrm{wks}$ & SGRQ \\
\hline Lotvall, 2012 [52] & NCT00731822 & $2-3$ & ICS+LABA; Placebo & $4 \mathrm{wks}$ & Trough FEV1 \\
\hline Kerwin, 2012 [53] & NCT00891462 & $2-3$ & LAMA; Placebo & $12 \mathrm{wks}$ & Trough FEV1, SGRQ \\
\hline Kerwin, 2012 [54] & NCT00929110 & $2-3$ & LAMA; Placebo & 52 wks & Trough FEV1, SGRQ \\
\hline Jones, 2012 [55] & NCT01001494 & $2-3$ & LAMA; Placebo & $24 \mathrm{wks}$ & SGRQ \\
\hline Hanania, 2012 [56] & NCT00606684 & $2-3$ & LABA; Placebo & 4 wks & Trough FEV1 \\
\hline Hanania, 2012 [57] & NCT00784550 & $2-3$ & ICS+LABA+LAMA; LAMA & $24 \mathrm{wks}$ & Trough FEV1 \\
\hline Kornmann, 2011 [58] & NCT00567996 & $2-3$ & LABA; Placebo & $12 \mathrm{wks}$ & SGRQ, SQRG Responders \\
\hline Kerwin, $2011[59]$ & NCT01072448; NCT01068600 & $2-3$ & LABA; Placebo & 12 wks & SGRQ \\
\hline Jones, $2011[60]$ & NCT00363896; NCT00358436 & $2-3$ & LAMA; Placebo & $52 \mathrm{wks}$ & SGRQ, SQRG Responders \\
\hline D'Urzo, 2011 [61] & NCT01005901 & $2-3$ & LAMA; Placebo & 26 wks & Trough FEV1, SGRQ \\
\hline Chapman, 2011 [62] & NCT00677807 & $2-3$ & LABA; Placebo & $52 \mathrm{wks}$ & Trough FEV1 \\
\hline Buhl, 2011 [63] & NCT00900731 & $2-3$ & LABA; LAMA & $12 \mathrm{wks}$ & Trough FEV1, SGRQ \\
\hline Bogdan, $2011[64]$ & NCT00628862 & $2-3$ & LABA; Placebo & 12 wks & Trough FEV1, SGRQ, SQRG Responders \\
\hline Donohue, 2010 [65] & NCT00463567 & $2-3$ & LABA; LAMA; Placebo & 26 wks & Trough FEV1, SGRQ \\
\hline Calverley, 2010 [66] & NCT476099 & 3 & ICS+LABA; LABA & 48 wks & Trough FEV1, SGRQ \\
\hline Bateman, $2010[67]$ & NCT00387088 & $2-3$ & LAMA; Placebo & $48 \mathrm{wks}$ & Trough FEV1, SGRQ, SQRG Responders \\
\hline Bateman, 2010 [68] & NCT00168844; NCT00168831 & $2-3$ & LAMA; Placebo & 48 wks & Trough FEV1, SGRQ \\
\hline Welte, 2009 [69] & NCT00496470 & & ICS+LABA+LAMA; LAMA & 12 wks & Trough FEV1, SGRQ, SQRG Responders \\
\hline Tashkin, 2009 [70] & & & LABA+LAMA; LAMA & $12 \mathrm{wks}$ & Trough FEV1, SGRQ \\
\hline Rennard, $2009^{\circ}$ [71] & NCT00206167 & $2-4$ & ICS+LABA; LABA; Placebo & $52 \mathrm{wks}$ & SGRQ \\
\hline Wedzicha, 2008 [72] & NCT00361959 & $3-4$ & ICS+LABA; LAMA & $2 \mathrm{yrs}$ & SGRQ, SQRG Responders \\
\hline Tonnel, 2008 [73] & & $2-3$ & LAMA; Placebo & $9 \mathrm{mths}$ & SGRQ, SQRG Responders \\
\hline Tashkin, 2008 [74] & NCT00206154 & $2-4$ & ICS+LABA; LABA; Placebo & $6 \mathrm{mths}$ & Trough FEV1, SGRQ \\
\hline Tashkin, 2008 [75] & NCT00144339 & $2-4$ & LAMA; Placebo & $4 \mathrm{yrs}$ & SQRG Responders \\
\hline Sin, 2008 [76] & NCT00120978 & $2-3$ & ICS+LABA; Placebo & 4 wks & SGRQ \\
\hline Rabe, 2008 [77] & NCT00239421 & 2 & LABA+LAMA; ICS+LABA & $6 \mathrm{wks}$ & Trough FEV1 \\
\hline Gross, 2008 [78] & NCT00215436 & $2-3$ & LABA; Placebo & $12 \mathrm{wks}$ & Trough FEV1, SGRQ \\
\hline Calverley, 2008 [79] & & $2-3$ & ICS; Placebo & $52 \mathrm{wks}$ & Trough FEV1, SGRQ \\
\hline Bateman, 2008 [80] & & $2-4$ & LAMA; ICS+LABA & $6 \mathrm{wks}$ & Trough FEV1 \\
\hline Zheng, 2007 [81] & & & ICS+LABA; Placebo & $24 \mathrm{wks}$ & Trough FEV1, SGRQ \\
\hline Um, 2007 [82] & & & LAMA; ICS+LAMA & $6 \mathrm{wks}$ & Trough FEV1, SGRQ, SQRG Responders \\
\hline Kardos, 2007 [83] & & 3 & ICS+LABA; LABA & 44 wks & SGRQ, SQRG Responders \\
\hline Freeman, 2007 [84] & NCT00274079 & $1-3$ & LAMA; Placebo & $12 \mathrm{wks}$ & Trough FEV1 \\
\hline Choudhury, 2007 [85] & NCT00440687 & & ICS; Placebo & $52 \mathrm{wks}$ & SGRQ \\
\hline Chan, 2007 [86] & & & LAMA; Placebo & 48 wks & Trough FEV1, SGRQ, SQRG Responders \\
\hline Cazzola, 2007 [87] & & $3-4$ & ICS+LABA; LAMA; ICS+LABA+LAMA & 3 mths & Trough FEV1 \\
\hline Baumgartner, 2007 [88] & & & LABA; Placebo & 12 wks & Trough FEV1, SGRQ \\
\hline Aaron, 2007 [89] & & & LAMA; LABA+LAMA; ICS+LABA+LAMA & 52 wks & Trough FEV1, SGRQ \\
\hline Verkindre, 2006 [90] & & $2-3$ & LAMA; Placebo & $12 \mathrm{wks}$ & Trough FEV1, SGRQ, SQRG Responders \\
\hline Stockley, 2006 [91] & & & LABA; Placebo & $52 \mathrm{wks}$ & SGRQ \\
\hline Wouters, 2005 [92] & & & LABA; ICS+LABA & 52 wks & SGRQ \\
\hline Covelli, 2005 [93] & & & LAMA; Placebo & $12 \mathrm{wks}$ & Trough FEV1 \\
\hline Casaburi, 2005 [94] & & & LAMA; Placebo & 25 wks & Trough FEV1, SGRQ \\
\hline Briggs, 2005 [95] & & $2-3$ & LAMA; LABA & $12 \mathrm{wks}$ & Trough FEV1 \\
\hline
\end{tabular}

Fig. 1. Network plot of inhaled medications compared in our network meta-analysis. The width of the lines represents the cumulative number of trials for each comparison.

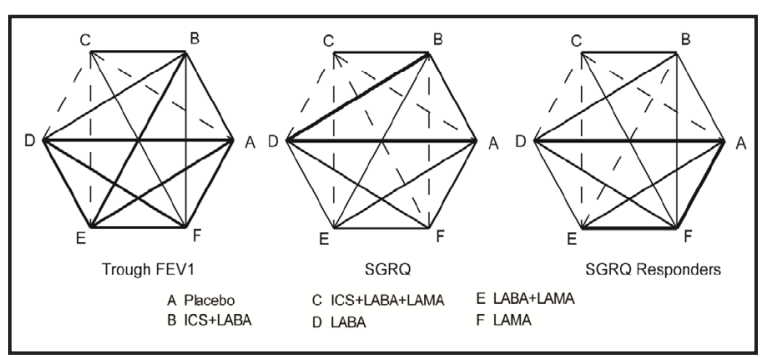


Table 2. Network meta-analysis results of raw mean differences and odds ratios between inhaled medications. Treatment: A = Placebo; B = ICS + LABA; C = ICS + LABA + LAMA; D = LABA; E = LABA + LAMA; F = LAMA. Abbreviation: Trough $\mathrm{FEV}_{1}=$ trough forced expiratory volume in 1 second; SGRQ = St George's Respiratory Questionnaire

\begin{tabular}{|c|c|c|c|c|c|c|}
\hline \multirow{6}{*}{ Trough FEV 1} & A & $0.11(0.08,0.15)$ & $0.22(0.16,0.29)$ & $0.07(0.04,0.10)$ & $0.16(0.13,0.19)$ & $0.10(0.07,0.13)$ \\
\hline & $-0.11(-0.15,-0.08)$ & B & $0.11(0.05,0.17)$ & $-0.05(-0.08,-0.01)$ & $0.05(0.01,0.08)$ & $-0.02(-0.05,0.02)$ \\
\hline & $-0.22(-0.29,-0.16)$ & $-0.11(-0.17,-0.05)$ & C & $-0.15(-0.22,-0.09)$ & $-0.06(-0.13,0.00)$ & $-0.12(-0.19,-0.06)$ \\
\hline & $-0.07(-0.10,-0.04)$ & $0.05(0.01,0.08)$ & $0.15(0.09,0.22)$ & D & $0.09(0.06,0.12)$ & $0.03(-0.00,0.06)$ \\
\hline & $-0.16(-0.19,-0.13)$ & $-0.05(-0.08,-0.01)$ & $0.06(-0.00,0.13)$ & $-0.09(-0.12,-0.06)$ & E & $-0.06(-0.10,-0.03)$ \\
\hline & $-0.10(-0.13,-0.07)$ & $0.02(-0.02,0.05)$ & $0.12(0.06,0.19)$ & $-0.03(-0.06,0.00)$ & $0.06(0.03,0.10)$ & $\mathbf{F}$ \\
\hline \multirow{6}{*}{ SGRQ Scores } & A & $3.20(1.29,5.13)$ & $3.69(0.41,6.95)$ & $2.03(0.45,3.64)$ & $2.00(-0.02,4.09)$ & $1.42(-0.47,3.39)$ \\
\hline & $-3.20(-5.13,-1.29)$ & $\mathbf{B}$ & $0.50(-2.18,3.09)$ & $-1.17(-2.85,0.49)$ & $-1.19(-3.37,1.11)$ & $-1.76(-4.01,0.48)$ \\
\hline & $-3.69(-6.95,-0.41)$ & $-0.50(-3.09,2.18)$ & C & $-1.63(-4.77,1.52)$ & $-1.68(-5.08,1.85)$ & $-2.26(-5.61,1.30)$ \\
\hline & $-2.03(-3.64,-0.45)$ & $1.17(-0.49,2.85)$ & $1.63(-1.52,4.77)$ & D & $-0.04(-2.02,2.10)$ & $-0.61(-2.34,1.17)$ \\
\hline & $-2.00(-4.09,0.02)$ & $1.19(-1.11,3.37)$ & $1.68(-1.85,5.08)$ & $0.04(-2.10,2.02)$ & E & $-0.58(-2.67,1.53)$ \\
\hline & $-1.42(-3.39,0.47)$ & $1.76(-0.48,4.01)$ & $2.26(-1.30,5.61)$ & $0.61(-1.17,2.34)$ & $0.58(-1.53,2.67)$ & $\mathbf{F}$ \\
\hline \multirow{6}{*}{$\begin{array}{c}\text { SGRQ } \\
\text { Responders }\end{array}$} & $\mathbf{A}$ & $1.76(1.52,2.05)$ & $2.23(1.78,2.82)$ & $1.42(1.29,1.59)$ & $1.94(1.75,2.19)$ & $1.44(1.33,1.57)$ \\
\hline & $0.57(0.49,0.66)$ & B & $1.27(1.02,1.59)$ & $0.80(0.70,0.92)$ & $1.10(0.94,1.28)$ & $0.82(0.71,0.93)$ \\
\hline & $0.45(0.36,0.56)$ & $0.79(0.63,0.98)$ & C & $0.64(0.51,0.80)$ & $0.87(0.69,1.10)$ & $0.64(0.52,0.80)$ \\
\hline & $0.70(0.63,0.78)$ & $1.24(1.09,1.42)$ & $1.57(1.25,1.98)$ & D & $1.37(1.22,1.53)$ & $1.01(0.92,1.11)$ \\
\hline & $0.52(0.46,0.57)$ & $0.91(0.78,1.07)$ & $1.15(0.91,1.45)$ & $0.73(0.65,0.82)$ & E & $0.74(0.67,0.81)$ \\
\hline & $0.70(0.64,0.75)$ & $1.22(1.07,1.41)$ & $1.55(1.24,1.94)$ & $0.99(0.90,1.09)$ & $1.35(1.23,1.49)$ & $\mathbf{F}$ \\
\hline
\end{tabular}

Fig. 2. Forest plots indicating the relative efficacy of inhaled medications (single or combined) with respect to $\mathrm{tFEV1,} \mathrm{SGRQ} \mathrm{and} \mathrm{SGRQ} \mathrm{responders.}$

Table 3. Network meta-analysis results of SUCRA values for all inhaled medications. ICS inhaled corticosteroid; LABA long-acting $\beta 2$-agonist; LAMA long-acting muscarinic antagonists; tFEV1 trough forced expiratory volume in 1 second; SGRQ St George's Respiratory Questionnaire

\begin{tabular}{lccc}
\hline Mechanism & Trough FEV1 & SGRQ & SGRQ Responders \\
\hline Placebo & 0.001 & 0.020 & 0.001 \\
ICS+LABA & 0.468 & 0.682 & 0.522 \\
ICS+LABA+LAMA & 0.828 & 0.700 & 0.812 \\
LABA & 0.173 & 0.418 & 0.230 \\
LABA+LAMA & 0.670 & 0.415 & 0.675 \\
LAMA & 0.362 & 0.272 & 0.270 \\
\hline
\end{tabular}
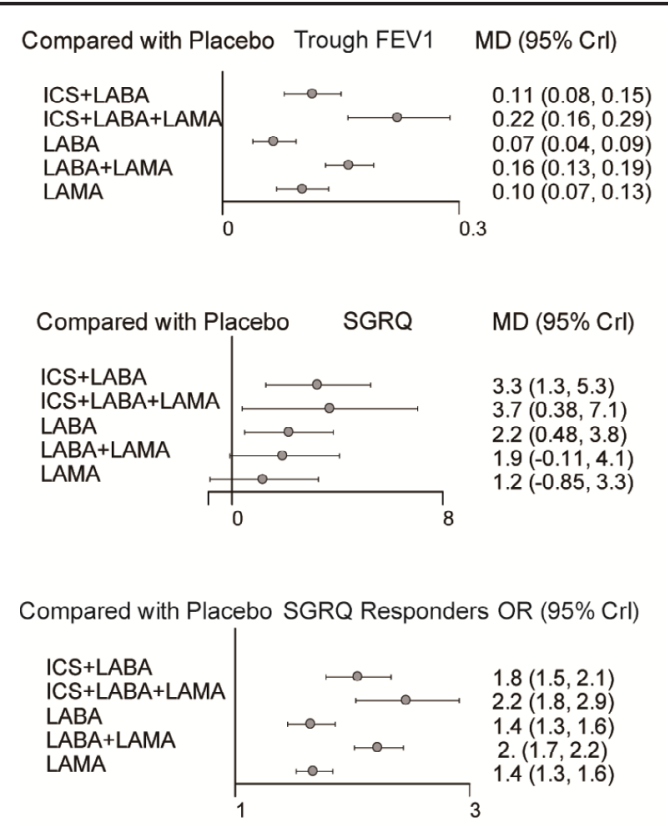

is no significant difference in changes of SGRQ scores between any other pairs of inhaled medications (Table 2, Fig. 2).

Comparing different inhaled medications by using SGRQ responders

The relative efficacy of inhaled medications is also assessed by using the binary outcome of SGRQ responders which indicates whether a patient had at least 4-unit reduction in SGRQ total score during the study period (from baseline to endpoint at the 24th week). Significantly increased ORs of SGRQ responders suggest that the inhaled medication is potentially more efficacious than the reference inhaled medication. Patients with all five inhaled medications exhibited significantly increased OR of SGRQ responders in reference to those with placebo (all ORs > 1). Besides that, patients with ICS + LABA + LAMA exhibited more favorable results compared to those with the following inhaled medications: ICS+LABA (OR $=1.76,95 \% \mathrm{CrI}$ $=1.52-2.05)$, LABA (OR $=1.42,95 \%$ CrI $=1.29-1.59)$ and LAMA $(O R=1.44,95 \% \mathrm{CrI}=1.33-$ 1.57; Table 2, Fig. 2). 


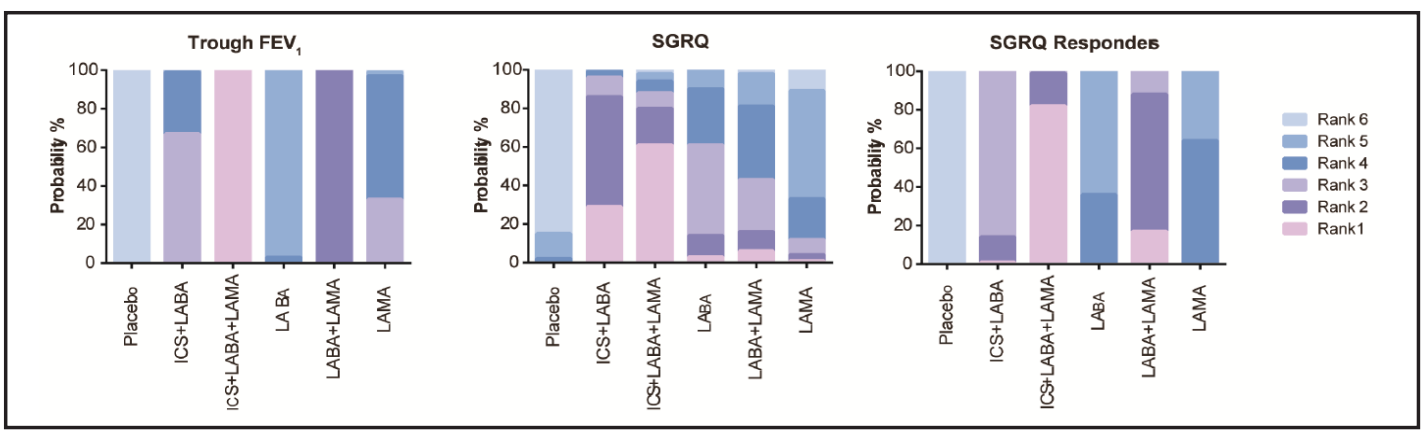

Fig. 3. Rank grams showing the cumulative probability of each inhaled medication for being the best, the second best and so on. Higher ranking are more preferable than lower rankings.

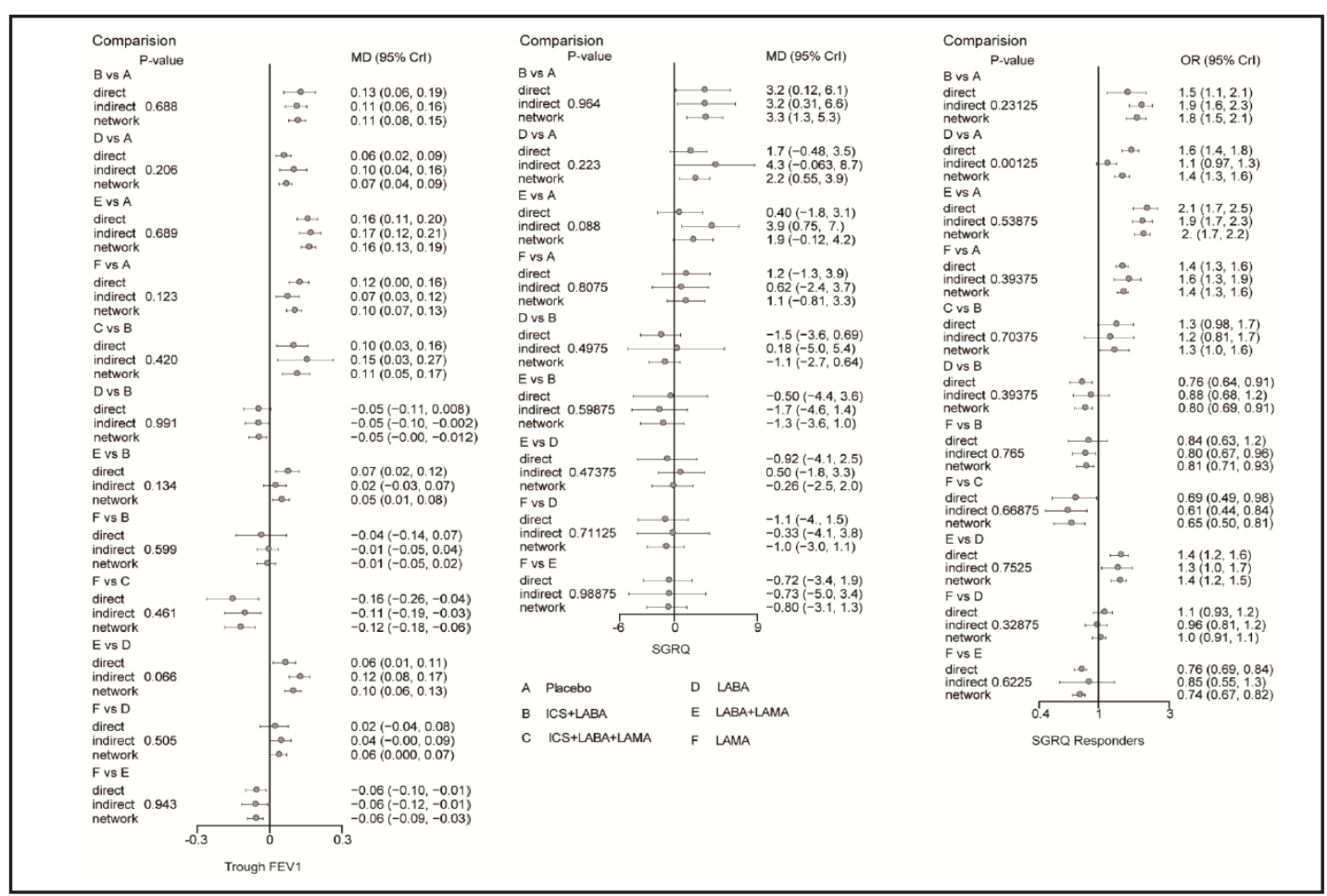

Fig. 4. Forest plots for node splitting methods suggesting the consistence between direct and indirect evidence for each comparison.

\section{Ranking of inhaled medications by using SUCRA}

Table 3 provides a comprehensive ranking of various inhaled medications when tFEV1, SGRQ and SGRQ responders were considered. The corresponding ranking of inhaled medications with respect to each endpoint is consistent with the results produced by our NMA. Incorporating ICS, LABA and LAMA for is ranked as the most preferable with respect to $\mathrm{tFEV}_{1}(\mathrm{SUCRA}=0.828)$. A similar ranking tendency of ICS + LABA + LAMA is observed in the other two endpoints: SGRQ (SUCRA $=0.700$ ) and SGRQ responders (SUCRA $=0.812)$. On the contrary, single inhaled medication of LABA or LAMA appears to have substantially lower values of SUCRA compared to that of ICS + LABA + LAMA. A ranking histogram comparing various inhaled medications (single or combined) with respect to tFEV1, SGRQ and SGRQ responders is presented in Figure 3. As suggested by the SUCRA values, combined triple inhaled medications may be more efficacious than single or dual inhaled medications.

\section{KARGER}




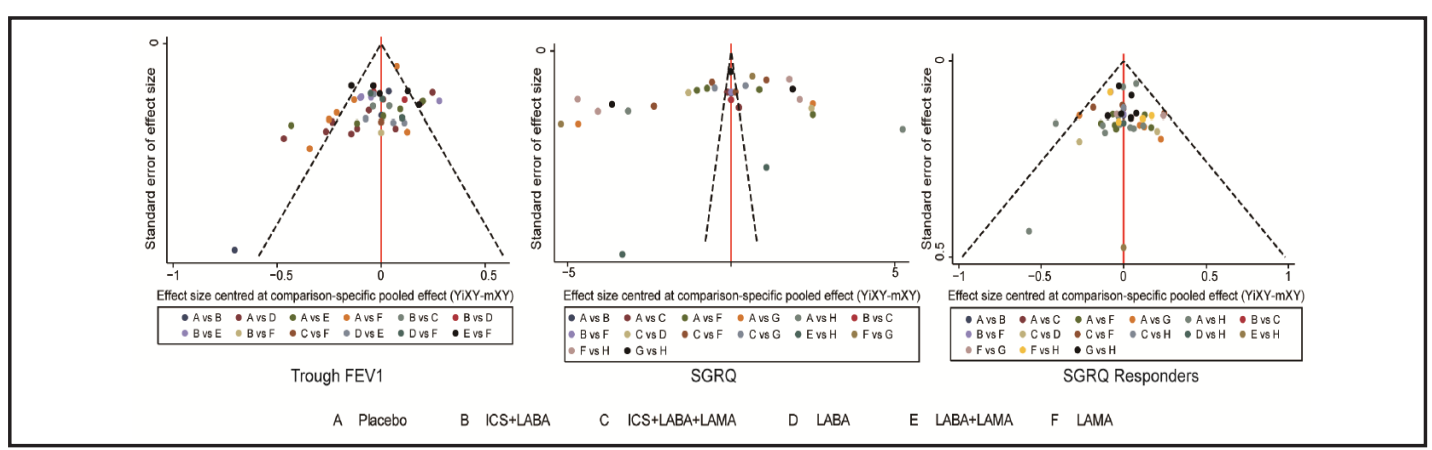

Fig. 5. Funnel plots for visulizing asymmeter patterns due to the presence of significant publication bias or small-study effects.

Assessing inconsistency between direct and indirect evidence

One fundamental assumption in our NMA is the adoption of a consistency model, in which the extent of consistency between direct and indirect evidence is validated by using the node splitting method. Evidence for each pairwise comparison obtained from direct evidence, indirect evidence and the network is compared using a node splitting forest plot (Fig. 4). A $P$-value of less than 0.05 suggests potentially significant inconsistency for that comparison. Hence, the consistency model assumption may be violated for that comparison. There is no significant inconsistency detected for each comparison with respect to $\mathrm{tFEV}_{1}$ or SGRQ (all $P$-value $>0.05$ ). However, the consistency model may not be appropriate for comparing placebo with LABA $(P$-value $=0.001)$ with respect to SGRQ responders. Since this is the only case in which potential significant inconsistency may arise from, we did not replace the consistency model in our NMA.

\section{Assessing small study effects and publication bias}

Although we did not conduct any formal statistical tests for small study effects or publication bias, a funnel plot was produced for each clinical outcome for this purpose. There is no obvious asymmetry pattern displayed in all of the three funnel plots. Thus, we do not have sufficient evidence to conclude significant small study effects or publication bias (Fig. 5).

\section{Discussion}

This NMA extends typical meta-analysis by simultaneously comparing several inhaled medications for COPD patients. In our study, COPD patients with the combined inhaled medications of ICS+LABA+LAMA were significantly associated with improved tFEV ${ }_{1}$, SGRQ and SGRQ Responders compared to those with single inhaled medication of LABA or LAMA. The above results were confirmed by both pooled row mean differences and ORs produced by our NMA. Furthermore, such a trend is consistent with the ranking scheme which is based on the SUCRA values of inhaled medications.

The Global Initiative for Chronic Obstructive Lung Disease (GOLD) suggests several diagnosis approaches for COPD: symptom evaluations, patient history evaluations, exposure to risk factors as well as post- bronchodilator spirometric assessments [96]. Once a COPD diagnosis is confirmed, a new disease classification approach which takes both symptoms and exacerbation risks into consideration can be used to categorize patients into four groups [96]. Inhaled medications are usually recommended to patients based on disease classification. Moreover, several inhaled medications may be combined for those who are classified as severe COPD.

LAMAs differ not only in their pharmacological characteristics but also in their mechanisms. For instance, the symptoms of COPD patients can be alleviated by Tiotropium whereas enhancing pulmonary functions can be achieved by using Glycopyrronium [97- 


\section{Cellular Physiology Cell Physiol Biochem 2017;41:1532-1546

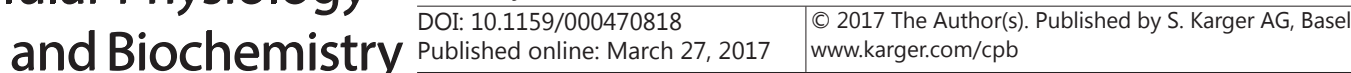 \\ Zhu et al.: Efficacy of Inhaled Medications for COPD}

99]. On the other hand, LABAs are particularly effective in broncho protection $[7,8]$. However, a single long-acting bronchodilator such as LAMA or LABA often does not provide adequate relief for some COPD patients. As a result, combining LABA with LAMA has been recommended by clinicians [10]. This recommendation has been confirmed in our NMA which revealed that COPD patients with LABA + LAMA exhibited stronger improvements in both $\mathrm{TFEV}_{1}$ and SGREQ scores compared to those with LABA or LAMA. This conclusion is consistent with results produced by other studies [2,100,101].

Another study conducted by Montuschi et al. indicated that triple inhaled medications (ICS+LABA+LAMA) may be particularly effective in patients with severe or very severe COPD. For those patients with severe COPD, maximizing bronchodilatation is the main objective. Results of Montuschi et al. are supported by the treatment recommendation guidelines provided by GOLD [102]. Also, our study appears to support the above conclusions because patients with ICS+LABA+LAMA were significantly associated with better tFEV ${ }_{1}$, SGRQ and SGRQ Responders in relation to those with other inhaled medications. However, the potential for increased side effects with combining therapies has not been taken into consideration [29, 33], and the use of steroids may raise potential risk for pneumonia [37]. As a result, whether the combination of ICS+LABA+LAMA can be a best choice for clinicians still need further proofs. Besides, stratified analysis by the severity of COPD is not feasible in our analysis due to the lack of information. Therefore the enhanced efficacy of triple inhaled medication should be further verified. As suggested by another retrospective study, COPD patients with TIO+LABA+ICS were associated with a reduced risk of mortality, COPD exacerbations and hospitalizations compared to matched COPD patients with LABA + ICS [102]. Simultaneously exploiting different inhaled medications may trigger additive or synergetic effects and may result in enhanced efficacy. This kind of enhancement may not be achievable by simply increasing the dose of a single bronchodilator [102, 103]. However, some inappropriate prescriptions of triple inhaled medications have been conducted by clinicians. The implementation of COPD guidelines should be strictly followed by clinicians in order to avoid the overuse of triple inhaled medications, particularly those with low risks or with less severe symptoms [104].

As the first Bayesian NMA, our study compares six inhaled medications by synthesizing all available evidence in the current literature. However, a few limitations contained in this study should be concerned. Firstly, there is significant variation in the number of studies for each inhaled medication (unbalanced design). For instance, the number of studies involved in ICS+LABA+LAMA is significantly fewer than that of others. This tends to result in wider confidence interval and lower statistical power. Secondly, variation in the sample size and study duration as well as other study characteristics may cause significant heterogeneity and thereby pooling evidence from individual studies with significant heterogeneity may not be comparable. Thirdly, we used a self-evaluated questionnaire (SGRQ) for assessing the health recovery status of COPD patients. However, the included studies did not disclose any information about non-responses to such a questionnaire. If a large proportion of patients in the included studies did not respond to the SGRQ, then the overall conclusion may be inaccurate. Another major limitation of our study is that the safety of triple inhaled medication was not assessed by our study. For instance, COPD patients with ICS+LABA were associated with an increased risk of adverse pneumonia events $[105,106]$. Therefore, clinicians should be mindful of the safety profile of dual or triple inhaled medications when making prescriptions. Besides, duration time of included studies are not consistent, and not all studies with long duration time such as 52 weeks or so have illustrated outcomes in 12 or 24 weeks, resulting in the difficulty and insufficiency of making a meta-analysis according to duration period.

For summary, combined inhaled medication of ICS+LABA+LAMA exhibited significant improvements in $\mathrm{HFEV}_{1}$, SGRQ and SGRQ Responders. Apart from that, combined dual inhaled medications such as LABA+LAMA and ICS+LABA are potentially more efficacious than single inhaled medication. Large scale randomized trials should be designed and implemented to confirmed the above conclusions. 


\section{Cellular Physiology Cell Physiol Biochem 2017;41:1532-1546 \begin{tabular}{l|l} 
DOI: 10.1159/000470818 & and Biochemistry 2017 The Author(s). Published by S. Karger AG, Basel \\
Published online:-Narch 27, 2017 & $\begin{array}{l}\text { www.karger.com/cpb } \\
\text { and }\end{array}$
\end{tabular} Zhu et al.: Efficacy of Inhaled Medications for COPD}

\section{Acknowledgements}

This study was supported by Natural Science Foundation of Technology Department in Yunnan Province (No. KKSY201326111) and the Applied Basic Research Project of Kunming Medical University (No. 201501U-D0706).

\section{Disclosure Statement}

No conflict of interest among all authors.

\section{References}

1 Topalovic M, Helsen T, Troosters T, Janssens W: Unexpected improvements of lung function in chronic obstructive pulmonary disease. Respir Med Case Rep 2016;18:81-84.

2 Oba Y, Sarva ST, Dias S: Efficacy and safety of long-acting beta-agonist/long-acting muscarinic antagonist combinations in COPD: a network meta-analysis. Thorax 2016;71:15-25.

3 Mirra V, Maglione M, Di Micco LL, Montella S, Santamaria F: Longitudinal Follow-up of Chronic Pulmonary Manifestations in Esophageal Atresia: A Clinical Algorithm and Review of the Literature. Pediatr Neonatol DOI:10.1016/j.pedneo.2016.03.0051-8.

-4 Farah R, Khamisy-Farah R, Makhoul N: [Survival of Patients with Worsening Chronic Obstructive Pulmonary Disease]. Harefuah 2016;155:205-209, 256.

-5 Vestbo J, Hurd SS, Agusti AG, Jones PW, Vogelmeier C, Anzueto A, Barnes PJ, Fabbri LM, Martinez FJ, Nishimura M, Stockley RA, Sin DD, Rodriguez-Roisin R: Global strategy for the diagnosis, management, and prevention of chronic obstructive pulmonary disease: GOLD executive summary. Am J Respir Crit Care Med 2013;187:347-365.

6 Oba Y, Lone NA: Comparative efficacy of long-acting muscarinic antagonists in preventing COPD exacerbations: a network meta-analysis and meta-regression. Ther Adv Respir Dis 2015;9:3-15.

7 Toy EL, Beaulieu NU, McHale JM, Welland TR, Plauschinat CA, Swensen A, Duh MS: Treatment of COPD: relationships between daily dosing frequency, adherence, resource use, and costs. Respir Med 2011;105:435-441.

8 Bouyssou T, Hoenke C, Rudolf K, Lustenberger P, Pestel S, Sieger P, Lotz R, Heine C, Buttner FH, Schnapp A, Konetzki I: Discovery of olodaterol, a novel inhaled beta2-adrenoceptor agonist with a $24 \mathrm{~h}$ bronchodilatory efficacy. Bioorg Med Chem Lett 2010;20:1410-1414.

$\checkmark 9$ Cazzola M, Lopez-Campos JL, Puente-Maestu L: The MABA approach: a new option to improve bronchodilator therapy. Eur Respir J 2013;42:885-887.

10 Feldman GJ, Edin A: The combination of umeclidinium bromide and vilanterol in the management of chronic obstructive pulmonary disease: current evidence and future prospects. Ther Adv Respir Dis 2013;7:311-319.

11 Beeh KM: "All I want for christmas is two": the advent of novel fixed-combination inhalers for COPD and outlook for 2014. Adv Ther 2013;30:1033-1037.

12 Shibata Y: [Role of ICS/LABA on COPD treatment]. Nihon Rinsho 2016;74:827-832.

13 Puhan MA, Bachmann LM, Kleijnen J, Ter Riet G, Kessels AG: Inhaled drugs to reduce exacerbations in patients with chronic obstructive pulmonary disease: a network meta-analysis. BMC Med 2009;7:2.

14 Liu Y, Shi H, Sun X, Zhang D, Zhang Y, Yang K, Mi L, Li M: Benefits of adding fluticasone propionate/ salmeterol to tiotropium in COPD: a meta-analysis. Eur J Intern Med 2014;25:491-495.

15 Rodrigo GJ, Plaza V, Castro-Rodriguez JA: Comparison of three combined pharmacological approaches with tiotropium monotherapy in stable moderate to severe COPD: a systematic review. Pulm Pharmacol Ther 2012;25:40-47.

16 Ichinose M, Takizawa A, Izumoto T, Tadayasu Y, Hamilton AL, Kunz C, Fukuchi Y: Efficacy and safety of the long-acting beta2-agonist olodaterol over 4 weeks in Japanese patients with chronic obstructive pulmonary disease. Int J Chron Obstruct Pulmon Dis 2015;10:1673-1683. 


\section{Cellular Physiology Cell Physiol Biochem 2017;41:1532-1546 \begin{tabular}{l|l|l} 
DOI: 10.1159/000470818 & and Biochemistry \\
Published onlne:1Varch 27, 2017 & $\begin{array}{l}\text { O 2017 The Author(s). Published by S. Karger AG, Basel } \\
\text { www.karger.com/cpb }\end{array}$
\end{tabular} \\ Zhu et al.: Efficacy of Inhaled Medications for COPD}

17 Fatima SS, Rehman R, Saifullah, Khan Y: Physical activity and its effect on forced expiratory volume. J Pak Med Assoc 2013;63:310-312.

18 Jones PW, Quirk FH, Baveystock CM: The St George's Respiratory Questionnaire. Respir Med 1991;85 Suppl B:25-31; discussion 33-27.

19 Wan X, Wang W, Liu J, Tong T: Estimating the sample mean and standard deviation from the sample size, median, range and/or interquartile range. BMC Med Res Methodol 2014;14:135.

20 Donegan S, Williamson P, D'Alessandro U, Tudur Smith C: Assessing key assumptions of network metaanalysis: a review of methods. Res Synth Methods 2013;4:291-323.

-21 Zhong N, Wang C, Zhou X, Zhang N, Humphries M, Wang L, Thach C, Patalano F, Banerji D: LANTERN: a randomized study of QVA149 versus salmeterol/fluticasone combination in patients with COPD. Int J Chron Obstruct Pulmon Dis 2015;10:1015-1026.

22 Zheng J, Zhong N, Newlands A, Church A, Goh AH: Efficacy and safety of once-daily inhaled umeclidinium/ vilanterol in Asian patients with COPD: results from a randomized, placebo-controlled study. Int J Chron Obstruct Pulmon Dis 2015;10:1753-1767.

23 Singh D, Worsley S, Zhu CQ, Hardaker L, Church A: Umeclidinium/vilanterol versus fluticasone propionate/ salmeterol in COPD: a randomised trial. BMC Pulm Med 2015;15:91.

24 Siler TM, Kerwin E, Sousa AR, Donald A, Ali R, Church A: Efficacy and safety of umeclidinium added to fluticasone furoate/vilanterol in chronic obstructive pulmonary disease: Results of two randomized studies. Respir Med 2015;109:1155-1163.

-25 Maleki-Yazdi MR, Beck E, Hamilton AL, Korducki L, Koker P, Fogarty C: A randomised, placebo-controlled, Phase II, dose-ranging trial of once-daily treatment with olodaterol, a novel long-acting $\beta 2$-agonist, for 4 weeks in patients with chronic obstructive pulmonary disease. Respir Med 2015;109:596-605.

26 Lee SH, Lee J, Yoo KH, Uh ST, Park MJ, Lee SY, Kim JY, Kim DK, Kim SJ, Lee KH, Yoo CG: Efficacy and safety of aclidinium bromide in patients with COPD: A phase 3 randomized clinical trial in a Korean population. Respirology 2015;20:1222-1228.

27 Frith PA, Thompson PJ, Ratnavadivel R, Chang CL, Bremner P, Day P, Frenzel C, Kurstjens N, Waddell A, Daniel A, Khoussousi A, Springfield A, Veale A, Graham AN, Gallagher B, Pande BR, O'Kane B, Jones C, Baldi C, Helm C, O'Dochartaigh C, Chambers D, Quinn D, Yull D, Karthigesu D, Then E, Graham F, Faigenbaum F, Geddam G, Cameron G, Blom H, Goldman H, Snell H, Chia I, Jeong J, Liew J, Salvaris J, Pryke J, Reid J, Kolbe J, O'Sullivan J, Pak J, Upham J, Feiber J, Ford JO, Yong K, Perrin K, Noonan L, Atlas L, Murdoch L, Pearce M, Bloch M, Holmes M, Chia M, Epton M, Leadston M, Tandon MK, Chitgopeker M, Liebenberg N, Hendry N, Olaniyi O, Singh O, Kendall P, Van Niekerk P, Willet R, Tomlins R, Pillay S, Sharifeh S, Carson S, Bingham S, Walford T, Erasmus T, Claridge T, Hess Z: Glycopyrronium once-daily significantly improves lung function and health status when combined with salmeterol/fluticasone in patients with COPD: The GLISTEN study A randomised controlled trial. Thorax 2015;70:519-527.

28 Donohue JF, Worsley S, Zhu CQ, Hardaker L, Church A: Improvements in lung function with umeclidinium/ vilanterol versus fluticasone propionate/salmeterol in patients with moderate-to-severe COPD and infrequent exacerbations. Respir Med 2015;109:870-881.

29 Buhl R, Maltais F, Abrahams R, Bjermer L, Derom E, Ferguson G, Flezar M, Hebert J, McGarvey L, Pizzichini E, Reid J, Veale A, Gronke L, Hamilton A, Korducki L, Tetzlaff K, Waitere-Wijker S, Watz H, Bateman E: Tiotropium and olodaterol fixed-dose combination versus mono-components in COPD (GOLD 2-4). Eur Respir J 2015;45:969-979.

30 Buhl R, Gessner C, Schuermann W, Foerster K, Sieder C, Hiltl S, Korn S: Efficacy and safety of once-daily QVA149 compared with the free combination of once-daily tiotropium plus twice-daily formoterol in patients with moderate-to-severe COPD (QUANTIFY): a randomised, non-inferiority study. Thorax 2015;70:311-319.

-31 Beeh KM, Westerman J, Kirsten AM, Hebert J, Gronke L, Hamilton A, Tetzlaff K, Derom E: The 24-h lungfunction profile of once-daily tiotropium and olodaterol fixed-dose combination in chronic obstructive pulmonary disease. Pulm Pharmacol Ther 2015;32:53-59.

-32 Aalbers R, Maleki-Yazdi MR, Hamilton A, Waitere-Wijker S, Zhao Y, Amatto VC, Schmidt O, Bjermer L: Randomized, Double-Blind, Dose-Finding Study for Tiotropium when Added to Olodaterol, Administered via the Respimat $\AA$ Inhaler in Patients with Chronic Obstructive Pulmonary Disease. Adv Ther 2015;32:809-822. 


\section{Cellular Physiology Cell Physiol Biochem 2017;41:1532-1546 \begin{tabular}{l|l} 
and Biochemistry Published online: March 27, 2017 & $\begin{array}{l}\text { (c) } 2017 \text { The Author(s). Published by S. Karger AG, Basel } \\
\text { www.karger.com/cpb }\end{array}$
\end{tabular} \\ Zhu et al.: Efficacy of Inhaled Medications for COPD}

-33 ZuWallack R, Allen L, Hernandez G, Ting N, Abrahams R: Efficacy and safety of combining olodaterol Respimat $₫$ and tiotropium HandiHaler $₫$ in patients with COPD: Results of two randomized, double-blind, active-controlled studies. Int J Chron Obstruct Pulmon Dis 2014;9:1133-1144.

-34 Trivedi R, Richard N, Mehta R, Church A: Umeclidinium in patients with COPD: a randomised, placebocontrolled study. Eur Respir J 2014;43:72-81.

- 35 Singh D, Jones PW, Bateman ED, Korn S, Serra C, Molins E, Caracta C, Gil EG, Leselbaum A: Efficacy and safety of aclidinium bromide/formoterol fumarate fixed-dose combinations compared with individual components and placebo in patients with COPD (ACLIFORM-COPD): a multicentre, randomised study. BMC Pulm Med 2014;14:178.

-36 Pepin JL, Cockcroft JR, Midwinter D, Sharma S, Rubin DB, Andreas S: Long-acting bronchodilators and arterial stiffness in patients with COPD: a comparison of fluticasone furoate/vilanterol with tiotropium. Chest 2014;146:1521-1530.

-37 Ohar JA, Crater GD, Emmett A, Ferro TJ, Morris AN, Raphiou I, Sriram PS, Dransfield MT: Fluticasone propionate/salmeterol 250/50 $\mu$ g versus salmeterol $50 \mu \mathrm{g}$ after chronic obstructive pulmonary disease exacerbation. Respir Res 2014;15:

- 38 Maltais F, Singh S, Donald AC, Crater G, Church A, Goh AH, Riley JH: Effects of a combination of umeclidinium/vilanterol on exercise endurance in patients with chronic obstructive pulmonary disease: two randomized, double-blind clinical trials. Ther Adv Respir Dis 2014;8:169-181.

-39 Maleki-Yazdi MR, Kaelin T, Richard N, Zvarich M, Church A: Efficacy and safety of umeclidinium/vilanterol 62.5/25 mcg and tiotropium $18 \mathrm{mcg}$ in chronic obstructive pulmonary disease: results of a 24-week, randomized, controlled trial. Respir Med 2014;108:1752-1760.

-40 Feldman GJ, Bernstein JA, Hamilton A, Nivens MC, Korducki L, LaForce C: The 24-h FEV1 time profile of olodaterol once daily via Respimat(R) and formoterol twice daily via Aerolizer(R) in patients with GOLD 2-4 COPD: results from two 6-week crossover studies. Springerplus 2014;3:419.

-41 D'Urzo AD, Rennard SI, Kerwin EM, Mergel V, Leselbaum AR, Caracta CF: Efficacy and safety of fixed-dose combinations of aclidinium bromide/formoterol fumarate: the 24-week, randomized, placebo-controlled AUGMENT COPD study. Respir Res 2014;15:123.

42 Donohue JF, Hanania NA, Make B, Miles MC, Mahler DA, Curry L, Tosiello R, Wheeler A, Tashkin DP: Oneyear safety and efficacy study of arformoterol tartrate in patients with moderate to severe COPD. Chest 2014;146:1531-1542.

-43 Celli B, Crater G, Kilbride S, Mehta R, Tabberer M, Kalberg CJ, Church A: Once-daily umeclidinium/ vilanterol 125/25 $\mu \mathrm{g}$ therapy in COPD. Chest 2014;145:981-991.

44 Fukuchi Y, Samoro R, Fassakhov R, Taniguchi H, Ekelund J, Carlsson LG, Ichinose M: Budesonide/ formoterol via Turbuhaler(R) versus formoterol via Turbuhaler(R) in patients with moderate to severe chronic obstructive pulmonary disease: phase III multinational study results. Respirology 2013;18:866873.

45 Donohue JF, Maleki-Yazdi MR, Kilbride S, Mehta R, Kalberg C, Church A: Efficacy and safety of once-daily umeclidinium/vilanterol 62.5/25 mcg in COPD. Respir Med 2013;107:1538-1546.

-46 Decramer ML, Chapman KR, Dahl R, Frith P, Devouassoux G, Fritscher C, Cameron R, Shoaib M, Lawrence D, Young D, McBryan D, investigators I: Once-daily indacaterol versus tiotropium for patients with severe chronic obstructive pulmonary disease (INVIGORATE): a randomised, blinded, parallel-group study. Lancet Respir Med 2013;1:524-533.

-47 Cooper CB, Celli BR, Jardim JR, Wise RA, Legg D, Guo J, Kesten S: Treadmill endurance during 2-year treatment with tiotropium in patients with COPD: a randomized trial. Chest 2013;144:490-497.

48 Bateman ED, Ferguson GT, Barnes N, Gallagher N, Green Y, Henley M, Banerji D: Dual bronchodilation with QVA149 versus single bronchodilator therapy: the SHINE study. Eur Respir J 2013;42:1484-1494.

49 Tashkin DP, Doherty DE, Kerwin E, Matiz-Bueno CE, Knorr B, Shekar T, Gates D, Staudinger H: Efficacy and safety characteristics of mometasone furoate/formoterol fumarate fixed-dose combination in subjects with moderate to very severe COPD: findings from pooled analysis of two randomized, 52-week placebocontrolled trials. Int J Chron Obstruct Pulmon Dis 2012;7:73-86.

-50 Sharafkhaneh A, Southard JG, Goldman M, Uryniak T, Martin UJ: Effect of budesonide/formoterol pMDI on COPD exacerbations: a double-blind, randomized study. Respir Med 2012;106:257-268. 


\section{Cellular Physiology Cell Physiol Biochem 2017;41:1532-1546 \begin{tabular}{l|l} 
and Biochemistry Published online: March 27, 2017 & $\begin{array}{l}\text { (c) } 2017 \text { The Author(s). Published by S. Karger AG, Basel } \\
\text { www.karger.com/cpb }\end{array}$
\end{tabular} \\ Zhu et al.: Efficacy of Inhaled Medications for COPD}

51 Scherr A, Schafroth Torok S, Jochmann A, Miedinger D, Maier S, Taegtmeyer AB, Chhajed PN, Tamm MT, Leuppi JD: Response to add-on inhaled corticosteroids in COPD based on airway hyperresponsiveness to mannitol. Chest 2012;142:919-926.

52 Lotvall J, Bakke PS, Bjermer L, Steinshamn S, Scott-Wilson C, Crim C, Sanford L, Haumann B: Efficacy and safety of 4 weeks' treatment with combined fluticasone furoate/vilanterol in a single inhaler given once daily in COPD: a placebo-controlled randomised trial. BMJ Open 2012;2:e000370.

53 Kerwin EM, D'Urzo AD, Gelb AF, Lakkis H, Garcia Gil E, Caracta CF: Efficacy and safety of a 12-week treatment with twice-daily aclidinium bromide in COPD patients (ACCORD COPD I). COPD 2012;9:90-101.

-54 Kerwin E, Hebert J, Gallagher N, Martin C, Overend T, Alagappan VK, Lu Y, Banerji D: Efficacy and safety of NVA237 versus placebo and tiotropium in patients with COPD: the GLOW2 study. Eur Respir J 2012;40:1106-1114.

-55 Jones PW, Singh D, Bateman ED, Agusti A, Lamarca R, de Miquel G, Segarra R, Caracta C, Garcia Gil E: Efficacy and safety of twice-daily aclidinium bromide in COPD patients: the ATTAIN study. Eur Respir J 2012;40:830-836.

-56 Hanania NA, Feldman G, Zachgo W, Shim JJ, Crim C, Sanford L, Lettis S, Barnhart F, Haumann B: The efficacy and safety of the novel long-acting beta2 agonist vilanterol in patients with COPD: a randomized placebocontrolled trial. Chest 2012;142:119-127.

57 Hanania NA, Crater GD, Morris AN, Emmett AH, O'Dell DM, Niewoehner DE: Benefits of adding fluticasone propionate/salmeterol to tiotropium in moderate to severe COPD. Respir Med 2012;106:91-101.

-58 Kornmann O, Dahl R, Centanni S, Dogra A, Owen R, Lassen C, Kramer B: Once-daily indacaterol versus twice-daily salmeterol for COPD: a placebo-controlled comparison. Eur Respir J 2011;37:273-279.

59 Kerwin EM, Gotfried MH, Lawrence D, Lassen C, Kramer B: Efficacy and Tolerability of Indacaterol 75 $\mu \mathrm{g}$ Once Daily in Patients Aged $\geq 40$ Years With Chronic Obstructive Pulmonary Disease: Results From 2 Double-Blind, Placebo-Controlled 12-Week Studies. Clin Ther 2011;33:1974-1984.

60 Jones PW, Rennard SI, Agusti A, Chanez P, Magnussen H, Fabbri L, Donohue JF, Bateman ED, Gross NJ, Lamarca R, Caracta C, Gil EG: Efficacy and safety of once-daily aclidinium in chronic obstructive pulmonary disease. Respir Res 2011;12:55.

61 D'Urzo A, Ferguson GT, van Noord JA, Hirata K, Martin C, Horton R, Lu Y, Banerji D, Overend T: Efficacy and safety of once-daily NVA237 in patients with moderate-to-severe COPD: the GLOW1 trial. Respir Res 2011;12:156.

62 Chapman KR, Rennard SI, Dogra A, Owen R, Lassen C, Kramer B: Long-term safety and efficacy of indacaterol, a long-acting beta(2)-agonist, in subjects with COPD: a randomized, placebo-controlled study. Chest 2011;140:68-75.

63 Buhl R, Dunn LJ, Disdier C, Lassen C, Amos C, Henley M, Kramer B: Blinded 12-week comparison of oncedaily indacaterol and tiotropium in COPD. Eur Respir J 2011;38:797-803.

-64 Bogdan MA, Aizawa H, Fukuchi Y, Mishima M, Nishimura M, Ichinose M: Efficacy and safety of inhaled formoterol 4.5 and 9 mug twice daily in Japanese and European COPD patients: phase III study results. BMC Pulm Med 2011;11:51.

65 Donohue JF, Fogarty C, Lotvall J, Mahler DA, Worth H, Yorgancioglu A, Iqbal A, Swales J, Owen R, Higgins M, Kramer B: Once-daily bronchodilators for chronic obstructive pulmonary disease: indacaterol versus tiotropium. Am J Respir Crit Care Med 2010;182:155-162.

-66 Calverley PM, Kuna P, Monso E, Costantini M, Petruzzelli S, Sergio F, Varoli G, Papi A, Brusasco V: Beclomethasone/formoterol in the management of COPD: a randomised controlled trial. Respir Med 2010;104:1858-1868.

67 Bateman ED, Tashkin D, Siafakas N, Dahl R, Towse L, Massey D, Pavia D, Zhong NS: A one-year trial of tiotropium Respimat plus usual therapy in COPD patients. Respir Med 2010;104:1460-1472.

68 Bateman E, Singh D, Smith D, Disse B, Towse L, Massey D, Blatchford J, Pavia D, Hodder R: Efficacy and safety of tiotropium Respimat SMI in COPD in two 1-year randomized studies. Int J Chron Obstruct Pulmon Dis 2010;5:197-208.

69 Welte T, Miravitlles M, Hernandez P, Eriksson G, Peterson S, Polanowski T, Kessler R: Efficacy and tolerability of budesonide/formoterol added to tiotropium in patients with chronic obstructive pulmonary disease. Am J Respir Crit Care Med 2009;180:741-750.

70 Tashkin DP, Pearle J, Iezzoni D, Varghese ST: Formoterol and tiotropium compared with tiotropium alone for treatment of COPD. COPD 2009;6:17-25. 


\section{Cellular Physiology Cell Physiol Biochem 2017;41:1532-1546 \begin{tabular}{l|l} 
and Biochemistry Published online: March 27, 2017 & $\begin{array}{l}\text { (c) } 2017 \text { The Author(s). Published by S. Karger AG, Basel } \\
\text { www.karger.com/cpb }\end{array}$
\end{tabular} \\ Zhu et al.: Efficacy of Inhaled Medications for COPD}

71 Rennard SI, Tashkin DP, McElhattan J, Goldman M, Ramachandran S, Martin UJ, Silkoff PE: Efficacy and tolerability of budesonide/formoterol in one hydrofluoroalkane pressurized metered-dose inhaler in patients with chronic obstructive pulmonary disease: results from a 1-year randomized controlled clinical trial. Drugs 2009;69:549-565.

-72 Wedzicha JA, Calverley PM, Seemungal TA, Hagan G, Ansari Z, Stockley RA: The prevention of chronic obstructive pulmonary disease exacerbations by salmeterol/fluticasone propionate or tiotropium bromide. Am J Respir Crit Care Med 2008;177:19-26.

-73 Tonnel AB, Perez T, Grosbois JM, Verkindre C, Bravo ML, Brun M: Effect of tiotropium on health-related quality of life as a primary efficacy endpoint in COPD. Int J Chron Obstruct Pulmon Dis 2008;3:301-310.

74 Tashkin DP, Rennard SI, Martin P, Ramachandran S, Martin UJ, Silkoff PE, Goldman M: Efficacy and safety of budesonide and formoterol in one pressurized metered-dose inhaler in patients with moderate to very severe chronic obstructive pulmonary disease: results of a 6-month randomized clinical trial. Drugs 2008;68:1975-2000.

75 Tashkin DP, Celli B, Senn S, Burkhart D, Kesten S, Menjoge S, Decramer M: A 4-year trial of tiotropium in chronic obstructive pulmonary disease. N Engl J Med 2008;359:1543-1554.

76 Sin DD, Man SF, Marciniuk DD, Ford G, FitzGerald M, Wong E, York E, Mainra RR, Ramesh W, Melenka LS, Wilde E, Cowie RL, Williams D, Gan WQ, Rousseau R: The effects of fluticasone with or without salmeterol on systemic biomarkers of inflammation in chronic obstructive pulmonary disease. Am J Respir Crit Care Med 2008;177:1207-1214.

77 Rabe KF, Timmer W, Sagkriotis A, Viel K: Comparison of a combination of tiotropium plus formoterol to salmeterol plus fluticasone in moderate COPD. Chest 2008;134:255-262.

78 Gross NJ, Nelson HS, Lapidus RJ, Dunn L, Lynn L, Rinehart M, Denis-Mize K: Efficacy and safety of formoterol fumarate delivered by nebulization to COPD patients. Respir Med 2008;102:189-197.

79 Calverley PM, Rennard S, Nelson HS, Karpel JP, Abbate EH, Stryszak P, Staudinger H: One-year treatment with mometasone furoate in chronic obstructive pulmonary disease. Respir Res 2008;9:73.

80 Bateman ED, van Dyk M, Sagriotis A: Comparable spirometric efficacy of tiotropium compared with salmeterol plus fluticasone in patients with COPD: a pilot study. Pulm Pharmacol Ther 2008;21:20-25.

-81 Zheng JP, Yang L, Wu YM, Chen P, Wen ZG, Huang WJ, Shi Y, Wang CZ, Huang SG, Sun TY, Wang GF, Xiong SD, Zhong NS: The efficacy and safety of combination salmeterol (50 microg)/fluticasone propionate (500 microg) inhalation twice daily via accuhaler in Chinese patients with COPD. Chest 2007;132:1756-1763.

82 Um SW, Yoo CG, Kim YW, Han SK, Shim YS: The combination of tiotropium and budesonide in the treatment of chronic obstructive pulmonary disease. J Korean Med Sci 2007;22:839-845.

83 Kardos P, Wencker M, Glaab T, Vogelmeier C: Impact of salmeterol/fluticasone propionate versus salmeterol on exacerbations in severe chronic obstructive pulmonary disease. Am J Respir Crit Care Med 2007;175:144-149.

84 Freeman D, Lee A, Price D: Efficacy and safety of tiotropium in COPD patients in primary care--the SPiRiva Usual CarE (SPRUCE) study. Respir Res 2007;8:45.

85 Choudhury AB, Dawson CM, Kilvington HE, Eldridge S, James WY, Wedzicha JA, Feder GS, Griffiths CJ: Withdrawal of inhaled corticosteroids in people with COPD in primary care: a randomised controlled trial. Respir Res 2007;8:93.

86 Chan CK, Maltais F, Sigouin C, Haddon JM, Ford GT: A randomized controlled trial to assess the efficacy of tiotropium in Canadian patients with chronic obstructive pulmonary disease. Can Respir J 2007;14:465-472.

87 Cazzola M, Andò F, Santus P, Ruggeri P, Di Marco F, Sanduzzi A, D'Amato M: A pilot study to assess the effects of combining fluticasone propionate/salmeterol and tiotropium on the airflow obstruction of patients with severe-to-very severe COPD. Pulm Pharmacol Ther 2007;20:556-561.

88 Baumgartner RA, Hanania NA, Calhoun WJ, Sahn SA, Sciarappa K, Hanrahan JP: Nebulized arformoterol in patients with COPD: a 12-week, multicenter, randomized, double-blind, double-dummy, placebo- and activecontrolled trial. Clin Ther 2007;29:261-278.

89 Aaron SD, Vandemheen KL, Fergusson D, Maltais F, Bourbeau J, Goldstein R, Balter M, O'Donnell D, McIvor A, Sharma S, Bishop G, Anthony J, Cowie R, Field S, Hirsch A, Hernandez P, Rivington R, Road J, Hoffstein V, Hodder R, Marciniuk D, McCormack D, Fox G, Cox G, Prins HB, Ford G, Bleskie D, Doucette S, Mayers I, Chapman K, Zamel N, FitzGerald M: Tiotropium in combination with placebo, salmeterol, or fluticasonesalmeterol for treatment of chronic obstructive pulmonary disease: a randomized trial. Ann Intern Med 2007;146:545-555. 


\section{Cellular Physiology Cell Physiol Biochem 2017;41:1532-1546 \begin{tabular}{l|l} 
DOI: 10.1159/000470818 & $\begin{array}{l}\text { O 2017 The Author(s). Published by S. Karger AG, Basel } \\
\text { www.karger.com/cpb }\end{array}$ \\
\hline
\end{tabular} \\ Zhu et al.: Efficacy of Inhaled Medications for COPD}

90 Verkindre C, Bart F, Aguilaniu B, Fortin F, Guerin JC, Le Merre C, Iacono P, Huchon G: The effect of tiotropium on hyperinflation and exercise capacity in chronic obstructive pulmonary disease. Respiration 2006;73:420-427.

-91 Stockley RA, Chopra N, Rice L: Addition of salmeterol to existing treatment in patients with COPD: a 12 month study. Thorax 2006;61:122-128.

-92 Wouters EFM, Postma DS, Fokkens B, Hop WCJ, Prins J, Kuipers AF, Pasma HR, Hensing CAJ, Creutzberg EC: Withdrawal of fluticasone propionate from combined salmeterol/fluticasone treatment in patients with COPD causes immediate and sustained disease deterioration: A randomised controlled trial. Thorax 2005;60:480-487.

93 Covelli H, Bhattacharya S, Cassino C, Conoscenti C, Kesten S: Absence of electrocardiographic findings and improved function with once-daily tiotropium in patients with chronic obstructive pulmonary disease. Pharmacotherapy 2005;25:1708-1718.

-94 Casaburi R, Kukafka D, Cooper CB, Witek Jr TJ, Kesten S: Improvement in exercise tolerance with the combination of tiotropium and pulmonary rehabilitation in patients with COPD. Chest 2005;127:809-817.

95 Briggs DD, Jr., Covelli H, Lapidus R, Bhattycharya S, Kesten S, Cassino C: Improved daytime spirometric efficacy of tiotropium compared with salmeterol in patients with COPD. Pulm Pharmacol Ther 2005;18:397-404.

-96 Davis KJ, Landis SH, Oh YM, Mannino DM, Han MK, van der Molen T, Aisanov Z, Menezes AM, Ichinose M, Muellerova H: Continuing to Confront COPD International Physician Survey: physician knowledge and application of COPD management guidelines in 12 countries. Int J Chron Obstruct Pulmon Dis 2015;10:3955.

-97 Barr RG, Bourbeau J, Camargo CA, Ram FS: Tiotropium for stable chronic obstructive pulmonary disease: A meta-analysis. Thorax 2006;61:854-862.

$\$ 98$ Karner C, Cates CJ: Long-acting beta(2)-agonist in addition to tiotropium versus either tiotropium or long-acting beta(2)-agonist alone for chronic obstructive pulmonary disease. Cochrane Database Syst Rev DOI:10.1002/14651858.CD008989.pub2CD008989.

-99 Ulrik CS: Once-daily glycopyrronium bromide, a long-acting muscarinic antagonist, for chronic obstructive pulmonary disease: a systematic review of clinical benefit. Int J Chron Obstruct Pulmon Dis 2012;7:673678.

100 Schlueter M, Gonzalez-Rojas N, Baldwin M, Groenke L, Voss F, Reason T: Comparative efficacy of fixed-dose combinations of long-acting muscarinic antagonists and long-acting beta2-agonists: a systematic review and network meta-analysis. Ther Adv Respir Dis 2016;10:89-104.

101 Huisman EL, Cockle SM, Ismaila AS, Karabis A, Punekar YS: Comparative efficacy of combination bronchodilator therapies in COPD: a network meta-analysis. Int J Chron Obstruct Pulmon Dis 2015;10:1863-1881.

102 Montuschi P, Malerba M, Macis G, Mores N, Santini G: Triple inhaled therapy for chronic obstructive pulmonary disease. Drug Discov Today 2016;21:1820-1827.

103 Montuschi P, Ciabattoni G: Bronchodilating drugs for chronic obstructive pulmonary disease: current status and future trends. J Med Chem 2015;58:4131-4164.

104 Brusselle G, Price D, Gruffydd-Jones K, Miravitlles M, Keininger DL, Stewart R, Baldwin M, Jones RC: The inevitable drift to triple therapy in COPD: an analysis of prescribing pathways in the UK. Int J Chron Obstruct Pulmon Dis 2015;10:2207-2217.

105 Kew KM, Seniukovich A: Inhaled steroids and risk of pneumonia for chronic obstructive pulmonary disease. Cochrane Database Syst Rev DOI:10.1002/14651858.CD010115.pub2CD010115.

106 Dransfield MT, Bourbeau J, Jones PW, Hanania NA, Mahler DA, Vestbo J, Wachtel A, Martinez FJ, Barnhart F, Sanford L, Lettis S, Crim C, Calverley PM: Once-daily inhaled fluticasone furoate and vilanterol versus vilanterol only for prevention of exacerbations of COPD: two replicate double-blind, parallel-group, randomised controlled trials. Lancet Respir Med 2013;1:210-223. 